\title{
Bacterial Contamination and Microflora of Several Fresh Produce
}

\section{Soli, Kevin Webby}

Laboratory of Food Hygienic Chemistry, Division of Food Science and Biotechnology, Department of Bioscience and Biotechnology, Graduate School of Bioresource and Bioenvironmental Sciences, Kyushu University

\section{Yoshizumi, Asako}

Laboratory of Food Hygienic Chemistry, Division of Food Science and Biotechnology, Department of Bioscience and Biotechnology, Graduate School of Bioresource and Bioenvironmental Sciences, Kyushu University

\section{Yamakawa, Mami}

Laboratory of Food Hygienic Chemistry, Division of Food Science and Biotechnology, Department of Bioscience and Biotechnology, Graduate School of Bioresource and Bioenvironmental Sciences, Kyushu University

\section{Mishima, Tomoko}

Laboratory of Food Hygienic Chemistry, Division of Food Science and Biotechnology, Department of Bioscience and Biotechnology, Graduate School of Bioresource and Bioenvironmental Sciences, Kyushu University

他

https://doi . org/10.5109/18841

出版情報：九州大学大学院農学研究院紀要. 55 (2)，pp. 269-273，2010-10-29. Faculty of Agriculture, Kyushu University バージョン :

権利関係 : 


\title{
Bacterial Contamination and Microflora of Several Fresh Produce
}

\section{Kevin Webby SOLI ${ }^{1}$, Asako YOSHIZUMI' ${ }^{1}$, Mami YAMAKAWA ${ }^{1}$, Tomoko MISHIMA ${ }^{1}$, Ken-ichi HONJOH and Takahisa MIYAMOTO*}

\author{
Laboratory of Food Hygienic Chemistry, Division of Food Science and Biotechnology, \\ Department of Bioscience and Biotechnology, Faculty of Agriculture, \\ Kyushu University, Fukuoka 812-8581, Japan \\ (Received June 24, 2010 and accepted July 9, 2010)
}

\begin{abstract}
Viable counts were enumerated in 36 raw samples of 19 different vegetables. Coliform, fecal coliform, and $E$. coli were determined in 31 vegetable samples. Tomato was found to have the lowest viable count of $2.12 \log \mathrm{cfu} / \mathrm{g}$ while radish sprout had the highest count of $9.05 \log \mathrm{cfu} / \mathrm{g}$. Although $E$. coli was not detected in all the vegetables tested, most of these vegetables were positive for fecal coliform. Viable counts of the tenth leaves from the outside were lower by only $1 \mathrm{log} \mathrm{cfu} / \mathrm{g}$ than that of the outermost leaves in cabbage and lettuce. Among viable counts of vegetable parts, celery leaves, lower stems in radish sprout, and spinach were found to have the highest viable counts of $7.28 \mathrm{log} \mathrm{cfu} / \mathrm{g}, 9.27 \mathrm{log} \mathrm{cfu} / \mathrm{g}$, and $6.10 \mathrm{log} \mathrm{cfu} / \mathrm{g}$ respectively while lower stem in parsley had the lowest count of $5.10 \mathrm{log} \mathrm{cfu} / \mathrm{g}$. The microflora of the four vegetables, celery, parsley, radish, and radish sprout were determined by using biochemical methods. There were 105, 50, 48, 130, and 61 bacterial isolates from celery, lettuce, parsley, radish, and radish sprout, respectively. The predominant bacterium on the four vegetables was about 30-60\% Gram-negative Flavobacterium or Xanthomonas. Other Gram-negative bacteria isolated from the vegetables include 11\% Neisseria or Veillnella (celery), 18\% Moraxella (radish), 15\% Alcaligenes and 12\% Pseudomonas (radish sprout) while Enterobacteriaceae accounted for less than 5\% for each of the flora of celery, parsley, and radish sprout. On the contrary, parsley had 25\% Kurthia or Bacillus, and 13\% Micrococcus, both Gram-positive.
\end{abstract}

\section{INTRODUCTION}

Consumption of fresh produce has increased, mainly because of heightened awareness of the benefits of a healthy diet. Leafy or salad vegetables are mainly eaten fresh and have become increasingly popular because of their high sensory quality and convenience (Lund, 1989). These vegetables are high in water, vitamins, minerals, and dietary fiber (Weerakkody, 2003). Minimal processing to which fresh produce is subjected renders vegetables to physiological deterioration, biochemical changes and microbial degradation of product (O'Beirne and Francis, 2003). Additionally, cut tissues release nutrients that support the growth of microflora present on raw produce (Li et al., 2001). Ready-to-use vegetables harbor large and diverse populations of microorganisms, and counts of 5.0-7.0 log cfu/g are frequently present. Eighty to ninety percent of bacteria are Gram-negative rods, predominantly Pseudomonas, Enterobacter or Erwinia species as reviewed by Francis et al. (1999). Fresh-cut vegetables retain much of their indigenous microflora after minimal processing, however, pathogens may form part of this microflora, posing a potential food safety problem (Francis, et al., 1999). Surveys of bagged salads often recover low numbers of enteropathogens (Szabo et al., 2000; Francis et al., 1999; Lin et al., 1996). According to the study of the disease risks of food groups by Adak et al. (2005), a low risk ratio for salad vegetables was

${ }^{1}$ Laboratory of Food Hygienic Chemistry, Division of Food Science and Biotechnology, Department of Bioscience and Biotechnology, Graduate School of Bioresource and Bioenvironmental Sciences, Kyushu University

* Corresponding author (E-mail: tmiyamot@agr.kyushu-u.ac.jp) reported even though fresh produce has a considerable impact on disease incidence in a population. A factor that impacts microbial quality is the increase in importation, which aims to meet consumer demands for a wide choice of exotic fruit and vegetables year-round. As hygiene standards of irrigation, at harvest, and during storage can vary widely in different countries, the potential for contamination of produce may increase. The objectives of this study are to determine the viable counts and the regions of natural bacterial contamination in various vegetables, and identify the microflora of celery, lettuce, parsley, radish, and radish sprouts that are distributed in Fukuoka area, using biochemical methods.

\section{MATERIALS AND METHODS}

\section{Preparation of vegetables}

Fresh vegetables used in this study were purchased from a local supermarket in Fukuoka, Japan, stored at $6{ }^{\circ} \mathrm{C}$ and used in experiments within $24 \mathrm{~h}$. The vegetables were manually trimmed to remove damaged leaves and stems, or cores of lettuce and cabbage, and briefly washed with deionized water to remove soil, or dirt.

\section{Measurement of viable counts, coliform, fecal coli- form and $E$. coli}

Excess water on vegetable leaves was removed before $25 \mathrm{~g}$ of each sample leaves was weighed into stomacher bags containing filter mesh. A 10-fold dilution was made after $225 \mathrm{~mL}$ of peptone water was added aseptically to the bag in a biosafety cabinet. The sample was homogenized for 1 min using a Masticator (IUL instruments, Barcelona, Spain). Filtrate of the homogenate was serially diluted into required concentrations. Aliquots of 
$0.1 \mathrm{~mL}$ were surface spread onto tryptic soy agar (TSA, Becton Dickinson) in duplicates and incubated at $25^{\circ} \mathrm{C}$ for $72 \mathrm{~h}$ for enumeration of total aerobic mesophilic microorganisms (viable count). For enumeration of viable counts of each of the leaves of cabbage, and lettuce, single leaves were weighed and added into stomacher bags and diluted 10-folds with sterile water and homogenized for $30 \mathrm{~s}$. For viable counts of parts of other vegetables, each plant was aseptically cut into three parts (leaf, upper and lower stems), weighed and diluted 10-folds with sterile water and homogenized for $30 \mathrm{~s}$. Coliform bacteria, fecal coliform, and $E$. coli were measured both qualitatively and quantitatively (3-tube MPN method) according to the standard method described by Pharmaceutical Society of Japan (2010). After the enumeration of viable cells, 50-200 colonies cultivated in the same plate were isolated for identification by biochemical tests.

\section{Identification of microflora}

General biochemical tests (Gibbs and Skinner, 1966) were carried out to identify genus of the microflora of vegetables based on culturable cells.

\section{RESULTS}

\section{Viable, coliform, and $E$. coli counts of various veg- etables}

Viable counts of 36 raw samples of 19 different vegetables were measured. Coliform, fecal coliform, and $E$. coli were determined in 31 vegetable samples. Table 1 shows the viable, coliform, fecal coliform, and E. coli counts of various vegetables commercially distributed in Fukuoka. The viable counts were distributed widely among the samples from $2.12 \log \mathrm{cfu} / \mathrm{g}$ (tomato) to $9.05 \log \mathrm{cfu} / \mathrm{g}$ (radish sprout). Although E. coli was not

Table 1. Viable, coliform, fecal coliform and $E$. coli counts of commercially available vegetables

\begin{tabular}{|c|c|c|c|c|}
\hline Vegetables & $\begin{array}{c}\text { viable counts } \\
(\log \mathrm{cfu} / \mathrm{g})\end{array}$ & $\begin{array}{c}\text { coliform } \\
(\log \mathrm{cfu} / 10 \mathrm{~g})\end{array}$ & $\begin{array}{c}\text { fecal coliform } \\
(\log \mathrm{cfu} / 10 \mathrm{~g})\end{array}$ & $\begin{array}{c}\text { E.coli } \\
(\log \mathrm{cfu} / 10 \mathrm{~g})\end{array}$ \\
\hline Asparagus & 4.78 & $>3.15$ & + & - \\
\hline Broccoli & 2.80 & 0.56 & - & - \\
\hline Cabbage 1 & 2.48 & 1.36 & + & - \\
\hline Cabbage 2 & 5.73 & $>3.15$ & - & - \\
\hline Celery & 7.03 & 1.97 & 0.56 & - \\
\hline Cucumber 1 & 5.92 & $>3.15$ & + & - \\
\hline Cucumber 2 & 4.77 & 1.63 & + & - \\
\hline Cucumber 3 & 5.93 & $>3.15$ & + & - \\
\hline Eggplant 1 & 4.70 & $>3.15$ & + & - \\
\hline Eggplant 2 & 4.95 & 2.38 & + & - \\
\hline Eggplant 3 & 4.79 & $>3.15$ & 0.56 & - \\
\hline Eggplant 4 & 5.03 & $>3.15$ & + & - \\
\hline Eggplant 5 & 4.75 & $>3.15$ & - & - \\
\hline Ginger & 3.57 & ND & $\mathrm{ND}$ & ND \\
\hline Japanese ginger & 7.36 & ND & ND & ND \\
\hline Komatsuna 1 & 5.93 & 1.97 & + & - \\
\hline Komatsuna 2 & 6.62 & $>3.15$ & + & - \\
\hline Leaf lettuce 1 & 5.92 & $>3.15$ & + & - \\
\hline Leaf lettuce 2 & 6.03 & 3.04 & + & - \\
\hline Leek 1 & 5.50 & $>3.15$ & + & - \\
\hline Leek 2 & 4.77 & 2.66 & + & - \\
\hline Lettuce 1 & 6.24 & $>3.15$ & - & - \\
\hline Lettuce 2 & 2.98 & 2.66 & + & - \\
\hline Mitsuba & 6.25 & $>3.15$ & - & - \\
\hline Oil-seed rape & 5.79 & 3.04 & + & - \\
\hline Perilla & 7.12 & ND & $\mathrm{ND}$ & ND \\
\hline Parsley & 6.36 & ND & ND & ND \\
\hline Radish sprout & 9.05 & ND & ND & ND \\
\hline Spinach 1 & 6.80 & $>3.15$ & + & - \\
\hline Spinach 2 & 7.95 & $>3.15$ & + & - \\
\hline Spinach 3 & 6.66 & $>3.15$ & + & - \\
\hline Tomato 1 & 2.67 & 2.66 & + & - \\
\hline Tomato 2 & 4.31 & 2.38 & + & - \\
\hline Tomato 3 & 5.24 & 2.66 & + & - \\
\hline Tomato 4 & 3.57 & 1.63 & + & - \\
\hline Tomato 5 & 2.12 & 1.97 & + & - \\
\hline
\end{tabular}


Table 2. Viable counts of each leaf of cabbage and lettuce

\begin{tabular}{|c|c|c|c|c|c|c|c|c|c|c|}
\hline \multirow{3}{*}{ Vegetables } & \multicolumn{10}{|c|}{ Viable counts (log cfu/g) of leaf } \\
\hline & \multirow{2}{*}{$\begin{array}{l}\text { Outermost } \\
1\end{array}$} & & & & & & & & $\longrightarrow$ & Inner \\
\hline & & 2 & 3 & 4 & 5 & 6 & 7 & 8 & 9 & 10 \\
\hline Cabbage & 6.49 & 6.55 & 6.63 & 6.58 & 6.11 & 6.37 & 5.47 & 5.51 & 5.56 & 5.46 \\
\hline Lettuce & 7.26 & 7.17 & 7.18 & 7.12 & 7.04 & 6.92 & 6.50 & 6.38 & 6.18 & 6.07 \\
\hline
\end{tabular}

detected in all the vegetables tested, most of these vegetables were positive for fecal coliform, suggesting that almost all of the vegetables were spotted with soil or water contaminated with animal feces recently. Coliform counts differed from one sample to another even with the same vegetable. The counts were relatively high in cucumber, eggplant, leek, lettuce, oil-seed rape, spinach, and tomato.

\section{Viable counts of parts of vegetables}

Viable counts of each leaf of cabbage and lettuce were measured and the results are shown in Table 2 . Counts of the tenth leaves were lower than those of the outermost leaves by only 1 log cfu/g in cabbage and lettuce. Outer leaves and surface of fresh produce are inevitably exposed to various handling processes before and after harvest, therefore affecting the viable counts of produce.

Viable counts of the leaf, upper stem, and lower stem

Table 3. Viable counts of parts of some vegetables

\begin{tabular}{lccc}
\hline \multirow{2}{*}{ Vegetables } & \multicolumn{3}{c}{ Viable counts (log cfu/g) of each part } \\
\cline { 2 - 4 } & leaf & upper stem & lower stem \\
\hline Celery & 7.28 & 5.89 & 5.88 \\
Parsley & 6.36 & 6.36 & 5.10 \\
Radish sprout & 8.96 & 8.50 & 9.27 \\
Spinach & 5.96 & 5.13 & 6.10
\end{tabular}

of celery, parsley, radish sprout, and spinach were measured and count of each part is shown in Table 3. Celery leaves, lower stems in radish sprout, and spinach were found to have the highest viable counts of $7.28 \mathrm{log} \mathrm{cfu} / \mathrm{g}$, $9.27 \mathrm{log} \mathrm{cfu} / \mathrm{g}$, and $6.10 \mathrm{log} \mathrm{cfu} / \mathrm{g}$ respectively while lower stem in parsley had the lowest count of $5.10 \mathrm{log} \mathrm{cfu} / \mathrm{g}$.

\section{Microflora of some vegetables}

Microflora of celery, lettuce, parsley, radish, and radish sprout were determined by biochemical tests and the ratio (\%) of the identified genera are shown in Table 4. There were 105 bacterial colonies with a viable count of $7.03 \mathrm{log} \mathrm{cfu} / \mathrm{g}$ from celery, 50 colonies (6.24 log $\mathrm{cfu} / \mathrm{g}$ ) from lettuce, 48 colonies (6.36 log $\mathrm{cfu} / \mathrm{g}$ ) from parsley, 61 colonies (5.22 log $\mathrm{cfu} / \mathrm{g}$ ) from radish, and 130 colonies (8.73 log $\mathrm{cfu} / \mathrm{g}$ ) from radish sprout that were isolated and identified respectively.

The predominant bacterium on celery was 30\% Flavobacterium or Xanthomonas followed by $11 \%$ Neisseria or Veillonella while each of the remaining bacteria was less than 10\%. Flavobacterium, Xanthomonas, Neisseria and Veillonella are Gramnegative bacteria including Enterobacteriaceae, which accounted for $4.8 \%$ of the flora.

The predominant bacterium on lettuce was $82 \%$ Flavobacterium or Xanthomonas followed by $12 \%$ Pseudomonas and 2\% Neisseria or Veillonella. Flavobacterium, Xanthomonas, Neisseria, Veillonella

Table 4. Microflora of some vegetables determined by biochemical tests

\begin{tabular}{|c|c|c|c|c|c|}
\hline \multirow{2}{*}{ Genus of bacteria } & \multicolumn{5}{|c|}{ Ratio (\%) } \\
\hline & Celery & Lettuce & Parsley & Radish & Radish sprout \\
\hline Acinetobacter & 1.9 & 0.0 & 0.0 & 1.6 & 2.3 \\
\hline Alcaligenes & 2.9 & 0.0 & 2.1 & 3.3 & 14.6 \\
\hline Enterobacteriaceae & 4.8 & 0.0 & 2.1 & 0.0 & 3.8 \\
\hline Flavobacterium or Xanthomonas & 30.5 & 82.0 & 50.0 & 63.9 & 46.2 \\
\hline Kurthia or Bacillus & 8.6 & 0.0 & 25.0 & 8.2 & 7.7 \\
\hline Lactobacillus & 4.8 & 0.0 & 0.0 & 0.0 & 0.0 \\
\hline Micrococcus & 8.6 & 0.0 & 12.5 & 0.0 & 1.5 \\
\hline Moraxella & 8.6 & 0.0 & 2.1 & 18.0 & 7.7 \\
\hline Neisseria or Veillonella & 11.4 & 2.0 & 2.1 & 1.6 & 0.8 \\
\hline Pseudomonas & 6.7 & 12.0 & 2.1 & 3.3 & 11.5 \\
\hline Staphylococcus & 1.9 & 0.0 & 0.0 & 0.0 & 0.0 \\
\hline Streptococcus & 2.9 & 0.0 & 0.0 & 0.0 & 0.0 \\
\hline Vibrio & 6.7 & 0.0 & 2.1 & 0.0 & 3.8 \\
\hline Others & 0.0 & 4.0 & 0.0 & 0.0 & 0.0 \\
\hline Total & 100.0 & 100.0 & 100.0 & 100.0 & 100.0 \\
\hline Number of isolates & 105 & 50 & 48 & 61 & 130 \\
\hline Viable counts (log cfu/g) & 7.03 & 6.24 & 6.36 & 5.22 & 8.73 \\
\hline
\end{tabular}


and Pseudomonas are Gram-negative bacteria.

The predominant bacterium on parsley was 50\% Flavobacterium or Xanthomonas followed by $25 \%$ Kurthia or Bacillus, 13\% Micrococcus, while each of the remaining bacteria was less than 3\%. Kurthia, Bacillus, and Micrococcus are Gram-positive bacteria. Enterobacteriaceae accounted for $2.1 \%$ of the flora.

The predominant bacterium on fresh radish was $64 \%$ Flavobacterium or Xanthomonas followed by $18 \%$ Gram-negative Moraxella, while each of the remaining bacteria was less than $10 \%$.

The predominant bacterium on radish sprout was 46\% Flavobacterium or Xanthomonas followed by $15 \%$ Alcaligenes, 12\% Pseudomonas, while each of the remaining bacteria was less than $10 \%$. Enterobacteriaceae accounted for 3.8\% of the flora.

\section{DISCUSSION}

Vegetables harbor large and diverse populations of microorganisms, and counts of 5.0-7.0 log cfu/g are frequently present. Eighty to ninety percent of bacteria are Gram-negative rods, predominantly Pseudomonas, Enterobacter or Erwinia species as reviewed by Francis et al. (1999). Furthermore, Konishi et al. (2001) reported that the standard plate counts of vegetables are widely distributed from less than 1.0 to $8.0 \mathrm{log} \mathrm{cfu} / \mathrm{g}$, and in particular, the counts of alfalfa and white radish sprouts were high at $7.0 \mathrm{log} \mathrm{cfu} / \mathrm{g}$. In our study, radish sprout had the highest count of $9.05 \log \mathrm{cfu} / \mathrm{g}$ among the 19 vegetables tested. It has been shown that a variety of foodborne pathogens are present in sprouts. Salmonella sp., Listeria monocytogenes, Staphylococcus aureus, Bacillus cereus and Aeromonas hydrophila have been isolated from sprouted seeds, such as alfalfa, cress, and soybean (Beuchat, 1996). E. coli 0157 and Salmonella have been reported to be the causative agents of outbreaks of foodborne illness associated with sprouts (Jackson, 1998). Prior to sprouting, seeds are contaminated with significant levels of microorganisms. Various surveys have revealed viable counts of 4.48-4.78 log cfu/g (Andrews et al., 1979), and $5.95 \mathrm{log} \mathrm{cfu} / \mathrm{g}$ (Andrews et al., 1982) on alfalfa seeds. Untreated or improperly treated water, animal waste or manure, poor sanitation of equipment and poor personal hygiene could be potential sources of contamination for seeds or sprouts at the sprouting facility (Beuchat, 1996). These contamination factors may have been the reason why the viable count was the highest in radish sprout.

Jacques et al. (1994) observed that there were greater bacterial population densities on outer leaves than on inner leaves of endive (salad vegetable) throughout the growing season. The differences were statistically significant for total bacterial populations at all sampling times and were often significant for fluorescent and pectolytic bacterial populations. We have also observed that the viable counts of the tenth leaves of both cabbage and lettuce were lower by only 1 log $\mathrm{cfu} / \mathrm{g}$ than that of the outermost leaves. Celery leaves, lower stems in radish sprout, and spinach were found to have the high- est viable counts of $7.28 \mathrm{log} \mathrm{cfu} / \mathrm{g}, 9.27 \mathrm{log} \mathrm{cfu} / \mathrm{g}$, and $6.10 \log \mathrm{cfu} / \mathrm{g}$ respectively while lower stem in parsley had the lowest count of $5.10 \mathrm{log} \mathrm{cfu} / \mathrm{g}$.

There were 105, 50, 48, 130, and 61 bacterial isolates from celery, lettuce, parsley, radish, and radish sprout, respectively. The predominant bacterium on all of the vegetables was about 30-60\% Gram-negative Flavobacterium or Xanthomonas. Other Gram-negative bacteria isolated from the vegetables include $11 \%$ Neisseria or Veillnella (celery), 18\% Moraxella (radish), 15\% Alcaligenes and 12\% Pseudomonas (lettuce and radish sprout). On the contrary, parsley had $25 \%$ Kurthia or Bacillus and 13\% Micrococcus, both Grampositive. Enterobacteriaceae was detected from celery, parsley, and radish sprout, suggesting the possibility of contamination with coliform, fecal coliform, E. coli or other pathogenic bacteria.

There is little data about interactions between pathogens and indigenous microflora of vegetable products (Francis et al., 1999). Knowing the microflora of vegetables will help us clarify the changes of microflora of different fresh produce after exposure to decontamination treatment that is aimed to ensure quality and prolong shelf-life of fresh produce.

\section{REFERENCES}

Adak, G. K., S. M. Meakins, H. Yip, B. A. Lopman, and S. J. O'Brien 2005 Disease risks from foods, England and Wales, 19962000. Emerg. Infect. Dis. 11: 365-372

Andrews, W. H., C. R. Wilson, P. L. Poelma, A. Romero, and P. B. Mislivec 1979 Bacteriological survey of sixty health foods. Appl. Environ. Microbiol. 37: 559-566

Andrews, W. H., P. B. Mislivec, C. R. Wilson, V. R. Bruce, P. L. Polema, R. Gibson, M. W. Trucksess, and K. Young 1982 Microbial hazards associated with bean sprouting. J. AOAC. 65: $241-248$

Beuchat, L. R. 1996 Pathogenic microorganisms associated with fresh produce. J. Food Prot. 59: 204-216

Francis, G. A., C. Thomas and D. O'Beirne 1999 The microbiological safety of minimally processed vegetables. Int. J. Food Sci Tech., 34: 1-22

Gibbs, B. M and P. A. Skinner, 1966 Identification methods for microbiologists (part A), Academic Press, London pp. $59-64$

Jackson, L. A. 1998 Overview of outbreaks of foodborne illness associated with fresh fruits and vegetables. Symposium on Fresh Fruits and Vegetables: Food Safety Challenges, Institute of Food Technologists and the National Center for Food Safety and Technology, Rosemont, IL, May 12-14

Jacques, M-A., L. L. Kinkel, and C. E. Morris 1994 Population Sizes, Immigration, and Growth of Epiphytic Bacteria on Leaves of Different Ages and Positions of Field-Grown Endive (Cichorium endivia var. latifolia). Appl. Environ. Microbiol. 61: 899-906

Konishi, N., A. Kai, S. Matsushita, Y. Noguchi, Y. Takahashi, K. Sekiguchi, T. Arai, S. Morozumi, and Y. Kokubo 2001 Bacterial contamination of fresh vegetables and epidemiological investigation of isolates. Jpn. J. Food. Microbiol., 18(1): 9-14

Li, Y., E. Brackett, R. L. Shewfelt, and L. R. Beuchat 2001 Changes in appearance and natural microflora on iceberg lettuce treated in warm, chlorinated water and then stored at refrigeration temperature. Food Microbiol., 18: 299-308

Lin, C-M., S. Y. Fernando, and C. Wei 1996 Occurrence of Listeria monocytogenes, Salmonella spp., Escherichia coli and E. coli $\mathrm{O} 157$ in vegetables salads. Food Control, 7: 
$135-140$

Lund, D. 1989 Food processing: from art to engineering. Food Technol., 43: 242-247

Muyzer, G., E. C. DE Waal, and A. G. Uitterlinden 1993 Profiling of complex microbial populations by denaturing gradient gel electrophoresis analysis of polymerase chain reactionamplified genes coding for 16S rRNA. Appl Environ Microb., 59: 695-700

O'Beirne, D. and G. A. Francis 2003 Reducing the pathogen risk in MAP-prepared produce. In R. Ahvenainen (Ed.) "Novel food packaging techniques". Cambridge, UK; Boca Raton, FL: Woodhead Publishing Limited/CRC Press LLC, pp. 231-286
Pfaller, M. A., I. Mujeeb, R. J. Hollis, R. N. Jones and G. V. Doern 2000 Evaluation of the discriminary powers of the dienes test and ribotyping as typing methods for proteus mirabilis. J. Food Microbiol., 38: 1077-1080

Pharmaceutical Society of Japan. (2010). "Methods of Analysis in Health Science", 73-77 (in Japanese).

Szabo, E. A., K. J. Scurrah, and J. M. Burrows 2000 Survey for psychrotrophic bacterial pathogens in minimally processed lettuce. Lett. Appl Microbiol., 30: 456-460

Weerakkody, W. A. P. 2003 Nutritional Value Of Fresh Leafy Vegetables As Affected By Pre-Harvest Factors. Acta Hort. 604: $511-515$ 